\title{
ABBREVIATED CHRONOLOGY OF POLITICAL EVENTS IN KENYA
}

1895 Establishment of a British protectorate over Kenya.

1901 Completion of the Uganda Railway (through Kenya).

1922 The "Harry Thuku riots" mark the beginning of modern nationalist protest.

1924 Formation of the Kikuyu Central Association.

1944 Formation of the Kenyan African Union (KAU).

1952 Declaration of a state of emergency in response to the Mau Mau uprising.

1954 Lyttelton Constitution provides for limited participation of elected Africans in the Kenya government.

1960 Lancaster House Conference accepts principle of majority rule and ultimate independence for Kenya.

Formation of Kenyan African National Union (KANU) and Kenyan African Democratic Union (KADU).

1961 KADU forms a government with white liberals.

Kenyatta is released from detention.

1962 KADU and KANU form a coalition government.

1963 (June 1) Kenya becomes independent under the "Majimbo" constitution with Kenyatta as prime minister.

1964 Voluntary dissolution of KADU and emergence of a de facto one-party state.

(December 12) Kenya becomes a republic with a unitary constitution and with Kenyatta as president.

1966 Formation of the Kenya People's Union (KPU).

"Little General Election." 
xxiv ABBREVIATED CHRONOLOGY OF POLITICAL EVENTS

1969 Assassination of Tom Mboya.

Reestablishment of a de facto one-party state.

1975 Assassination of J. M. Kariuki.

1976 The movement to change the constitution.

1978 Death of President Kenyatta and succession of Daniel arap Moi to the presidency.

1982 Coup attempt by the air force.

1989 Minister of Finance Saitoti becomes vice-president after Joseph Karanja's brief tenure in the office. 